\title{
ANALYSIS OF TRACKING HYDRAULIC DESIGNING PROCESS
}

\author{
Andi Sudahan, Rusdijanto*, Sudjatmiko \\ Department of Mechanical Engineering, University of Merdeka Malang \\ *Email corresponding author: rusdiyanto@unmer.ac.id
}

\begin{abstract}
The use of hydraulic systems for various applications supporting work equipment is very widely used because of the nature and strength of the good and easy in its design. Hydraulic tracking can be widely applied in various needs. The principle of this work tool is designed for the release of bearings / mounting on a shaft or a ball bearing house vertically or horizontally. From the results of the hydraulic tracking planning analysis using solid works software, in this simulation to find static nodal stress (the received tensile strength) obtained the highest load is shown in the orange part of the tool with a stress value of 17.49 million $\mathrm{N} / \mathrm{m} 2$, the load experienced is only $15 \%$ of the permitted maximum limit of $24,800,200,000 \mathrm{~N} /$ $\mathrm{m} 2$.then the strain that occurs in the highest value is shown on a scale with an orange of $0.03946 \mathrm{~mm}$ on the upper beam component, that value $<1 \mathrm{~mm}$ means that the hydraulic frame tracking can be used properly.
\end{abstract}

Keywords :hydraulic tracking, software solid works, stress, strain.

\section{INTRODUCTION}

The use of hydraulic systems for various applications of work support equipment is very widely used because of its good nature and strength and is easy to design. Hydraulic tracking can be widely applied in various needs. The principle of this work tool is designed for the removal of bearings on a shaft or a ball bearing housing vertically or horizontal.

According to research by Ulia Ridhani, et al., (2010), it aims to design a tool that works multifunctionally, namely being able to open and install bearings using tracking hydraulic. This tool makes it easier for everyone to do the job of installing and removing bearings. According to the research of Diana Khairani, et al., (2015), one of the hydraulics tracking factors that greatly affects the performance of the company / workshop is that the poor layout of the facilities will lead to poor material flow patterns and material movement.

In tracking hydraulic planning, material selection, construction calculations, and aesthetics of planning drawings are required. To support this planning, technical drawings that meet the requirements are required, so that they can be implemented in the community using 
machine components. The tracking hydraulic work pattern uses a pressing force, when the hydraulic jack is operated, the shaft under the hydraulic jack holder presses the shaft which is on the center support plate.

Based on the description above, the writer tries to plan a hydraulic tracking device that can be used multipurpose, so that it can be applied by the community to support work in the workshop. This study aims to plan the tracking hydraulic with a simple construction.

\section{METHODOLOGY}

The following figure shows the flowchart of this research. This research is conducted by doing several step, started with literature study and review, then followed by determining the variables and sketching the workpiece, and analyzed by utilizing solidworks.

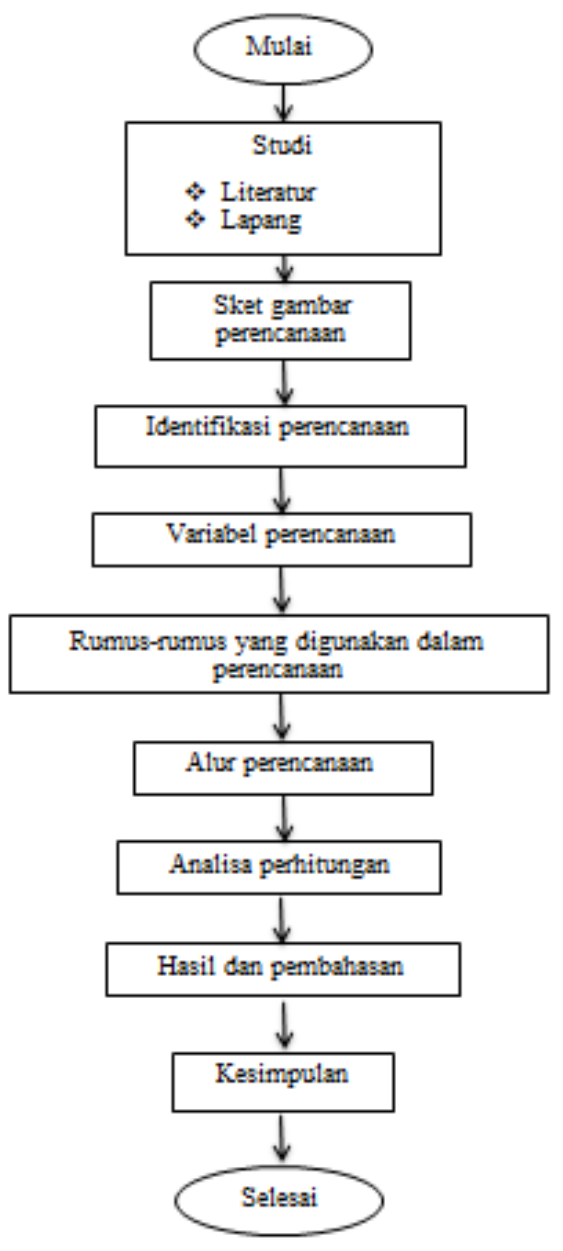

Figure 1. Flowchart

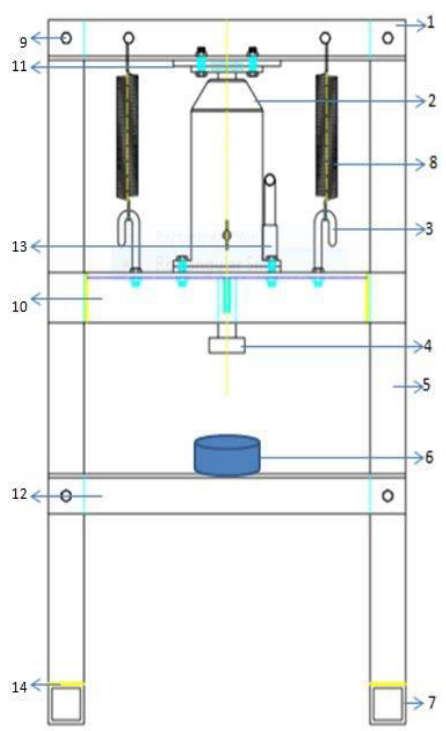

Figure 2. Hydraulic tracking design 
How to use the tracking hydraulic tool, first place the workpiece in the lower support position shown in Figure 3.2.no 12, with the shaft position vertically. Then the working tool in section 13, namely (hydraulic jack lever) is pumped to produce a compressive force in part number 2 (hydraulic jack), the pressure force produces a downward motion to push the shaft until the bearing is released from the shaft.

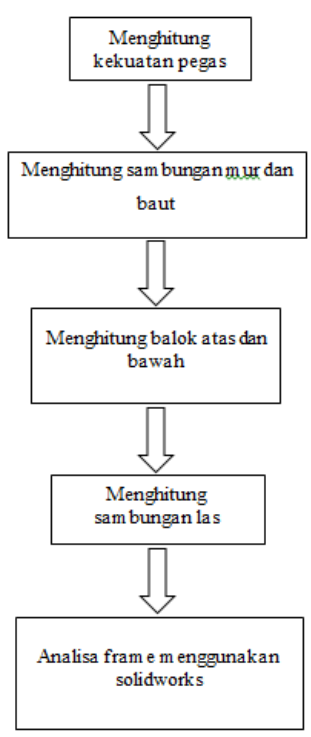

Figure 3. Design flowchart

\section{Calculation of Spring}

Initial data:

The weight of jack $\mathrm{W}_{\mathrm{D}}=3 \mathrm{~kg}$

Jack load capacity $\mathrm{W}_{\mathrm{F}} \quad=3000$ $\mathrm{kg}$
The weight of the jack support $\mathrm{W}_{\mathrm{T}}$ $=10 \mathrm{~kg}$

Total load for 2 springs $\quad \mathrm{W}_{\mathrm{C}}$

$$
=\left(\mathrm{W}_{\mathrm{D}}+\mathrm{W}_{\mathrm{F}}+\mathrm{W}_{\mathrm{T}}\right): 2
$$

$=(3+3000+10): 2$

$=1506,5 \mathrm{~kg}$

Diameter of spring D $=24$ $\mathrm{mm}$

Diameter of wire $\mathrm{d}=6$ $\mathrm{mm}$

(table 7.13 page 316 in Sularso's book)

Spring material $=$ the usual use of cold-formed SW symbol (table 7.11 p. 313) with hard steel wire, shear modulus price $\mathrm{G}=8 \times 10^{3}$ $\mathrm{kg} / \mathrm{mm}^{2}$,

$$
\begin{aligned}
& \text { Initial length } \mathrm{H}_{\mathrm{F}} \quad=150 \mathrm{~mm} \\
& \text { Free length } \mathrm{H}_{\mathrm{S}} \quad=221,5 \mathrm{~mm} \\
& \text { Deflection } \delta=20-30 \mathrm{~mm}
\end{aligned}
$$

- Moment of spring torsion $\mathrm{T}=(\mathrm{D} / 2) \mathrm{W}_{\mathrm{c}}$ Information:

$\mathrm{T}=$ Moment of Twist (mm.kg)

$\mathrm{D}=$ Diameter of spring $24 \mathrm{~mm}$

$\mathrm{W}_{\mathrm{c}}=$ Total load 1506,5 $\mathrm{kg}$ 


$$
\begin{aligned}
& =\left(\frac{24}{2}\right) 1506,5 \mathrm{~kg} \\
& =18078 \mathrm{~mm} . \mathrm{kg}
\end{aligned}
$$

- Moment withstand wire twisting

$\mathrm{Z}_{\mathrm{P}}=\left(\frac{\pi}{16}\right) \mathrm{d}^{3}$

Information:

$\mathrm{Z}_{\mathrm{P}}=$ Moment withstand wire twisting $\left(\mathrm{mm}^{3}\right)$

$\mathrm{d}=$ diameter of wire $6 \mathrm{~mm}$

$$
\begin{aligned}
Z_{P} & =\left(\frac{3,14}{16}\right) 6^{3} \\
& =0,2 \cdot 216 \mathrm{~mm}^{3} \\
& =43,2 \mathrm{~mm}^{3}
\end{aligned}
$$

\section{- Spring constant}

Spring constant (k) can be obtained from the equation:

$\mathrm{F}=\mathrm{k} \cdot \Delta \mathrm{X}$

Information:

$\mathrm{F}=$ the force working on the spring $=\mathrm{W}_{\mathrm{C}}=1506,5 \mathrm{~kg}$ $\mathrm{k}=$ Spring constant $\mathrm{kg} / \mathrm{mm}$ $\Delta \mathrm{X}=$ Deviation in spring length $\left(\mathrm{H}_{\mathrm{F}}-\mathrm{H}_{\mathrm{S}}\right)=71,5 \mathrm{~mm}$ $\mathrm{F}=\mathrm{k} . \Delta \mathrm{X}$

$1506,5 \mathrm{~kg}=\mathrm{k} \cdot 71,5 \mathrm{~mm}$

$\mathrm{k}=1506,5 \mathrm{~kg}: 71,5 \mathrm{~mm}$

$\mathrm{k}=21,6 \mathrm{~kg} / \mathrm{mm}$

So that when the length of the spring reaches $221.5 \mathrm{~mm}$ or experiences an elongation of $71.5 \mathrm{~mm}$ until the bearing condition is detached from the shaft, the force received by the spring is $1506.5 \mathrm{~kg}$, the magnitude of the force value is influenced by the jack capacity which reaches $3000 \mathrm{~kg}$.

\section{Calculation of bolt nut connection}

Initial data:

Load weight designed (WO) = $100 \mathrm{~kg}$

Correction factor $(\mathrm{Fc})$

$$
=1,2
$$

Axial tensile load on the bolt

$$
\begin{aligned}
(\mathrm{W}) & =\mathrm{FC} \cdot \mathrm{WO} \\
& =1,2 \cdot 100 \\
& =120 \mathrm{~kg}
\end{aligned}
$$

Core diameter radius $d_{1}=d_{1} / 2$

$$
=8,376 / 2=4,18
$$

Carbon clay steel bolt material (C) $0,22 \%$

\section{- Tensile stress}

$$
\begin{aligned}
\sigma_{t} & =\frac{W}{A} \\
A & =\pi r^{2} \\
& =3,14 \cdot 4,18^{2} \\
& =55,07 \mathrm{~mm} \\
\sigma_{t} & =\frac{120}{55,07}
\end{aligned}
$$


$=2,17 \mathrm{~kg} / \mathrm{mm}^{2}$

\section{- Outer thread diameter}

Coarse metric threads are

selected as initial data

Outer diameter $\mathrm{d} \quad=10$

$\mathrm{mm}$

Effective diameter $\mathrm{f} \mathrm{d}_{2}=9,026$

$\mathrm{mm}$

Core diameter $\mathrm{d}_{1} \quad=$

$8,376 \mathrm{~mm}$

Hook hight $\mathrm{H}_{1} \quad=0,812 \mathrm{~mm}$

Divider distance $\mathrm{P} \quad=1,5$

$\mathrm{mm}$

$d \geq \sqrt{\frac{4 w}{\pi \cdot \sigma_{a} \cdot 0,69}}$

$\geq \sqrt{\frac{4 \cdot 120}{3,14 \cdot 2,17 \cdot 0,69}}$

$\geq \sqrt{\frac{480}{3,19 \cdot 2,17 \cdot 0,64}}$

$\mathrm{d} \geq 10,5 \rightarrow 12 \mathrm{~mm}$

- Inner thread core diameter

$\mathrm{d}_{1} \geq \sqrt{\frac{4 \cdot w}{\pi \cdot \sigma_{a}}}$

$\geq \sqrt{\frac{4 \cdot 120}{3,14 \cdot 2,17}}$

$\geq 8,39 \rightarrow 8,39 \mathrm{~mm}$

\section{Welding calculation}

- Transverse joint weld strength
- Theoretical neck thickness

$$
\begin{aligned}
& a=\frac{t}{\sqrt{2}} \\
& =\frac{4}{\sqrt{2}} \\
& =0,285 \mathrm{~cm} \rightarrow 2,85 \mathrm{~mm}
\end{aligned}
$$

- The area of the weld

$$
\begin{aligned}
& A=\frac{t \cdot L}{\sqrt{2}} \\
& =\frac{0,4 \cdot 4}{\sqrt{2}} \\
& =1,14 \mathrm{~cm}^{2} \rightarrow 11,4 \mathrm{~mm}^{2}
\end{aligned}
$$

Frame planning using Solidwork software

- Solidworks calculation steps

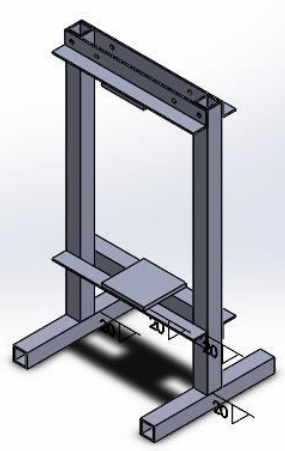

Figure 4. 3D tracking hydraulic

The simulation analysis process in solidwork software for hydraulic tracking tools is carried out as follows:

1. Depiction of $1 / 1 \quad 3 \mathrm{D}$ components in solidwork 
software according to 2D drawing dimensions

2. Combining of all 3D components on softwhare solidwork

3. Choose the simulation toll then proceed with

- The choice of the working force model is the static force

- Application of carbon steel material to the hydraulic traking frame

- The input of forces acting on the upper and lower pedestals is a reaction of the hydraulic jack work and several components that affect the working force.

- The input of connecting for each connection, for connecting using 2 types, namely bolts and nuts with dimensions obtained from manual calculations, welding joints which are also obtained from calculations.

- The input of components that do not move or as a lock, this is applied to the traking leg where the function of this component is to keep the hydraulic traking tool able to stand upright when it is given a force or not.

- Making mess so that the simulation can be done

- Run the results of inputting data to get a simulation image 1. Static nodal stress, 2. Statick strain and 3. Statick displacement.

According to the simulation results obtained 2 images, namely the form of extreme device deformation or the direction of the reaction of the force produced and the color scale to see the magnitude of the changes that occur from the three parameters obtained, namely 1. Static nodal stress, 2. Static strain and 3. Static displacement.

\section{a. Stress load}

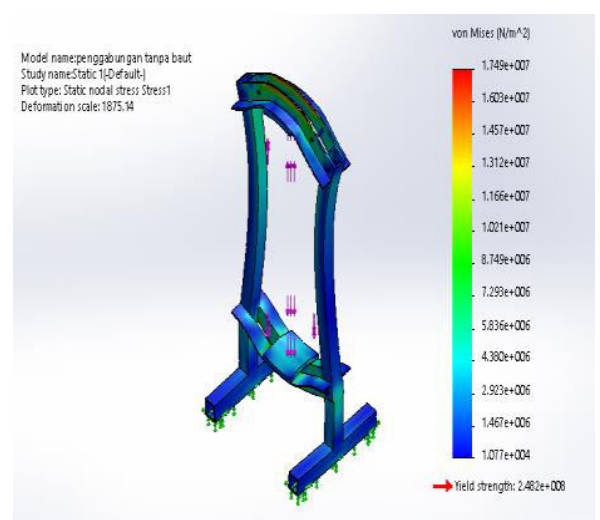

Figure 5. Received tensile strength

In this simulation, to determine the static nodal stress (tensile 
strength received), the highest load is shown on the tool part in orange with a stress value of $17.490 .000 \mathrm{~N} / \mathrm{m}^{2}$, the component that receives the highest load from all components is only the upper beam, this value considered safe because it is still below the tensile strength limit of $24,800,200,000 \mathrm{~N} / \mathrm{m}^{2}$, the largest load experienced is only $15 \%$ of the maximum allowable limit, this is influenced by the material used, namely S35C steel with a tensile strength of $52 \mathrm{~N} / \mathrm{mm}^{2}$ and the effect of the load. which works is 1506.5 $\mathrm{kg}$.

\section{b. Strain load}

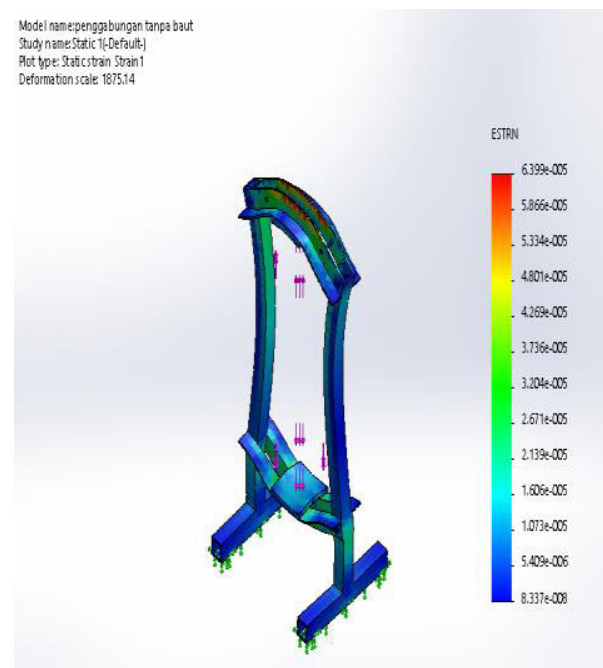

Figure 6. Structure changes

Strain is a distortion of the molecular structure of a material, relative to its "perfect" reaction state. Static implies an unchanging amount, so static strain is the distortion of a material that is currently unchanging. It can be seen in Figure 5 that the static strain simulation illustrates the change in the molecular structure of the hydraulic traking frame with S35C steel material and the load received is $1506.5 \mathrm{~kg}$, the highest value of molecular change is shown on the orange color scale with a value of 0.00006399 and reacts to the beam component. above, this happens because of the influence of the value of the reacting tensile strength.

\section{c. Displacement load}

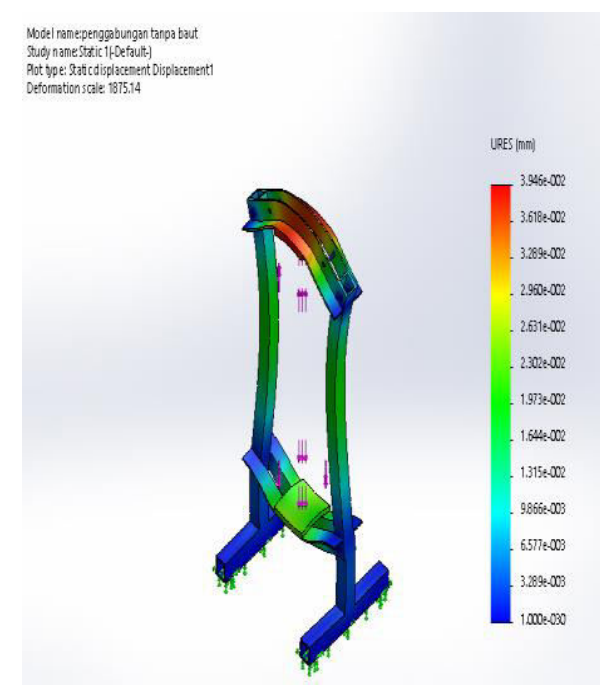

Figure 7. Strain

The dynamic load (strain) that reacts from the static load that works causes the hydraulic traking frame to experience strain, by looking at the color scale, the highest value is 
shown on the scale in orange, namely $0.03946 \mathrm{~mm}$ in the upper beam component, this means that the material used is steel. S35C and a working load of $1506.5 \mathrm{~kg}$, the hydraulic traking frame with components shown in orange has a strain of $0.03946 \mathrm{~mm}$, this value is $<1 \mathrm{~mm}$, meaning that the hydraulic frame when used does not experience significant strain and can be used properly.

\section{CONCLUSION}

Based on the analysis of the hydraulic tracking tool design, the following conclusions can be drawn:

1. Spring: diameter $\mathrm{D}=24 \mathrm{~mm}$

Diameter of wire $d=6$ $\mathrm{mm}$

Length of $\mathrm{H}_{\mathrm{F}} \quad=150$ $\mathrm{mm}$

Free length of $\mathrm{H}_{\mathrm{S}}=221,5$ $\mathrm{mm}$

Deflection $\delta=20$ $30 \mathrm{~mm}$

So that when the length of the spring reaches $221.5 \mathrm{~mm}$ or experiences an elongation of $71.5 \mathrm{~mm}$ until the bearing condition is detached from the shaft, the force received by the spring is $1506.5 \mathrm{~kg}$, the magnitude of the force value is influenced by the jack capacity which reaches $3000 \mathrm{~kg}$.

2. Nut and bolt

Tensile stress $=2,17 \mathrm{~kg} / \mathrm{mm}^{2}$

Outer thread diameter $=12 \mathrm{~mm}$ Inner thread core diameter $=$ $8,39 \mathrm{~mm}$

3. Welding $=$ theoretical neck thickness $=2,85 \mathrm{~mm}$

The resulting area $1,14 \mathrm{~cm}^{2} \rightarrow$ $11,4 \mathrm{~mm}^{2}$

4. Solidworks software

- This simulation is to determine the static nodal stress (tensile strength received), the highest load is shown in the tool part in orange with a stress value of 17.490.000 N / m2, the load experienced is only $15 \%$ of the maximum allowable limit.

- The highest value of the strain that occurs is shown on the scale in orange, namely $0.03946 \mathrm{~mm}$ on the upper beam component, this value $<1 \mathrm{~mm}$ means that the frame tracking hydraulic can be used properly 


\section{REFERENCES}

Diana Khairani Sofyan \& Syarifuddin. 2015. Perancangan Ulang Tata Letak Fasilitas Dengan Menggunakan Metode

Konvensional Berbasis 5s (Seiri, Seiton, Seiso, Seiketsu Dan Shitsuke).

Ulia Ridhani, Aminuddin, Riky Susanto, Adhim Abdul Jabbar, 2010. Rancang Bangun Alat Mounting Dan Dismounting Bearing Dengan Menggunakan Hydraulic Jack.

Nevada J.M Nanulaitta,.Alexander. A. Patty, 2011 Analisa Nilai Kekerasan Baja Karbon Rendah (S35c) Dengan Pengaruh Waktu Penahanan (Holding Time) Melalui Proses Pengarbonan Padat (Pack Carburizing) Dengan Pemanfaatan Cangkang Kerang. Andika syahrial lazuuardi., 2018, perencanaan sambungan mur dan baut pada gerobak sampah motor. Jurnal Mahasiswa Teknik Mesin Itn Malang

Didi muno irawan, Ganjar Iswantoro, Muhammad Hidayat Furqon, Sri Hastuti4， 2018. Pengaruh Nilai Konstanta Terhadap Pertambahan Panjang Pegas Pada Rangkaian Tunggal, Seri Dan Paralel
Mochamad Irsyadillah, 2016 Laporan Praktikumprogram Cadsolidworks

Solidworks, 2016

Sularso, 1997

Umar Sukrisno, 1983

Riswan Dwi Djamiko, 2008 Modul Teori Pengelasan

Beumer, B.J.M., 1994. Ilmu Bahan Logam., hal 20)

Yusuf bakhtiar, 2015. Analisis buckling terhadap tabung plat tipis menggunakan metode elemen hingga

Sukanto jatmiko, (2005), analisa kekuatan puntir dan kekuatan lentur putar Poros baja st 60 sebagai aplikasi perancangan bahan Poros baling-baling kapal. 